\title{
Efficacy of varicose vein surgery with preservation of the great safenous vein
}

\section{Eficácia do tratamento cirúrgico das varizes com preservação de veia safena interna}

Bernardo Cunha Senra Barros'; Antonio luiz de Araujo, tCBC-RJ2; Carlos Eduardo Virgini Magalhäes'; Raimundo luiz Senra Barros $^{3}$; Stenio Karlos Alvim Fiorelli2; Raphaella Ferreira Gatts'

A $B$ S T R A C T

\begin{abstract}
Objective: To evaluate the efficacy of surgical treatment of varicose veins with preservation of the great saphenous vein. Methods: We conducted a prospective study of 15 female patients between 25 and 55 years of age with clinical, etiologic, anatomic and pathophysiologic (CEAP) classification 2, 3 and 4. The patients underwent surgical treatment of primary varicose veins with great saphenous vein (GSV) preservation. Doppler ultrasonography exams were carried out in the first and third months postoperatively. The form of clinical severity of venous disease, Venous Clinical Severity Score (VCSS) was completed before and after surgery. We excluded patients with history of deep vein thrombosis, smoking or postoperatively use of elastic stockings or phlebotonics. Results: All patients had improved VCSS $(p<0.001)$ and reduction in the diameter of the great saphenous vein $(p$ $<0.001)$. There was a relationship between VCSS and the GSV caliber, as well as with preoperative CEAP. There was improvement in CEAP class in nine patients when compared with the preoperative period $(p<0.001)$. Conclusion: The varicose vein surgery with preservation of the great saphenous vein had beneficial effects to the GSV itself, with decreasing caliber, and to the symptoms when the vein had maximum caliber of $7.5 \mathrm{~mm}$, correlating directly with the CEAP. The decrease in GSV caliber, even without complete abolition of reflux, leads to clinical improvement by decreasing the reflux volume.
\end{abstract}

Key words: Venous insufficiency. Saphenous vein. Varicose veins. Saphenous vein/ultrasonography. Saphenous vein/surgery.

\section{INTRODUCTION}

C hronic venous insufficiency (CVI) is defined as an abnormality in the functioning of the venous system due to venous hypertension caused by venous reflux, obstruction of venous flow, or by the combination of these two factors ${ }^{1}$. CVI can affect the superficial venous system, the deep venous system, or both. Furthermore, the venous dysfunction may be the result of a congenital or acquired disorder ${ }^{2-4}$.

Reflux-induced venous hypertension can be caused by breakdown or damage to the venous valves; more recently, it is believed that the lesion and weakness of the vessel wall play a more important role in causing reflux and even in the genesis of valve disease ${ }^{1,5-7}$.

The prevalence of chronic venous insufficiency in the population increases with age. In Europe, 5 to 15\% of adults between 30 and 70 years of age have this disease, and $1 \%$ of them have varicose ulcers. In the United States, about seven million people have chronic venous insufficiency, which accounts for 70 to $90 \%$ of all lower extremity ulcers $^{8-10}$. The prevalence of primary venous disease can reach $20 \%$ of the population ${ }^{11}$. Maffei et al. ${ }^{12}$ conducted an epidemiological study on venous alterations of the lower limbs in the population of Botucatu / SP and found an estimated prevalence of $35.5 \%$ of varicose veins and $1.5 \%$ of severe forms of $\mathrm{CVI}$, with active or healed ulcers. With the aging of the world population, this prevalence tends to increase.

Being a chronic, progressive and relapsing character disease, CVI is still far from being understood and treated properly, although several theories and methods may be employed with relative immediate success, but without proven long-term results ${ }^{13}$.

Histological results of the saphenous vein wall with marked valvular insufficiency in patients with altered lipid profile show clear resulting subintimal thickening of intense reflux, hypertension and inflammatory reaction similar to atherosclerosis ${ }^{13}$.

Several methods have been used to assess the degree of CVI, such as the Venous Clinic Severity Score (VCSS), air plethysmography and echo-color-Doppler ${ }^{14-16}$, but none of them proved reliable stratification when relating clinical, etiologic, anatomic and pathophysiologic (CEAP) classification, nor has been successfully used to demonstrate efficacy of treatment methods.

1. Hospital Universitário Pedro Ernesto, Universidade Estadual do Rio de Janeiro (UERJ), Rio de Janeiro, Brazil; 2. Hospital Universitário Gaffrée e Guinle, Universidade Federal do Estado do Rio de Janeiro (UNIRIO), Rio de Janeiro, Brazil; 3. Hospital Municipal Miguel Couto, Rio de Janeiro, Brazil. 
The authors aimed to evaluate the importance of surgical treatment of lower limb varicose veins with preservation of the great saphenous vein in clinical regression of chronic venous disease.

\section{METHODS}

We evaluated a total of 22 lower limbs of 15 female patients with chronic venous insufficiency (CVI), according to the clinical, etiologic, anatomic and pathophysiologic classification. The patients underwent a preoperative protocol for surgical treatment of primary varicose veins of the lower limbs with preservation of the greater saphenous vein ${ }^{17}$. The VCSS form was completed before and after surgery to assess venous disease clinical severity.

The inclusion criteria adopted were: 1) female patient; 2) aged between 25 and 55 years; 3) diagnosis of chronic venous insufficiency (CEAP classification - clinical, etiologic, anatomic and pathophysiologic - between 2 and 4); 4) surgical treatment; 5) insufficiency in at least one of the saphenous veins; and 6) Maximum $7.5 \mathrm{~mm}$ diameter of the great saphenous vein. Exclusion criteria were: 1) history of lower limbs deep vein thrombosis); 2) smoking; 3) use of compression socks or phlebotonic medication postoperatively; 4) postoperative complications such as deep venous thrombosis or infection; 5) maximum diameter of the greater saphenous vein greater than $7.5 \mathrm{~mm}$; and 6) prior saphenectomy.

Patients were treated at the Vascular Surgery clinic, Hospital Universitário Gaffree e Guinle, Hospital Universitário Pedro Ernesto and VASCLAR Clinic. The selection was made from the history and physical examination of each patient (CEAP classification and VCSS). All patients underwent examination with eco-color-Doppler to identify and classify the degrees of venous insufficiency, completing the CEAP classification.

Postoperatively, patients were followed with queries made at one week, one month and three months after surgery. Each evaluation consisted of clinical history, physical examination and venous echo-color-Doppler exam of the lower limbs. The comparative analysis was performed between the results of the three tests applied during the visits.

The varicose paths were marked in standing position. Patients received spinal anesthesia and sedation and underwent surgery in the supine and Trendelenburg positions. The varicose paths were resected after ligation of insufficient veins directly and indirectly communicating to the great saphenous vein, which was preserved.

The main indicators in the evaluation of the great saphenous vein by Doppler ultrasonography were: the diameter of the vein in the groin, thigh and leg; the presence of insufficiency and the location of the insufficiency. These indicators were evaluated preoperatively and postoperatively, and subsequently compared.

The following parameters were evaluated: VCSS, diameter and insufficiency of the great saphenous vein (GSV), CEAP classification between the pre- and postoperative periods, as well as differences in individuals within the CEAP classification. For the statistical analysis we used the Student's t test $(p<0.05)$.

\section{RESULTS}

We operated, between August 2011 and August 2012, 15 female patients between 25 and 55 years of age, bearers of varicose veins. All patients (Figure 1) improved clinical criteria (VCSS) postoperatively $(p<0.001)$ and there was decrease in the diameter of the great saphenous vein $(p=0.002)$ (Figure 2).

We observed that there was no postoperative improvement of the CEAP class in 11 patients, one patient showing improvement of CEAP classification in one of the limbs $(p<0.001)$ (Table 1). There was restoration of the flow of the great saphenous vein in seven operated legs, with statistical significance $(p=0.001)$ (Table 2$)$. There was a directly proportional relationship between the VCSS and the great saphenous vein diameter, and the preoperative clinical, etiologic, anatomic and pathophysiologic classification (Table 3).

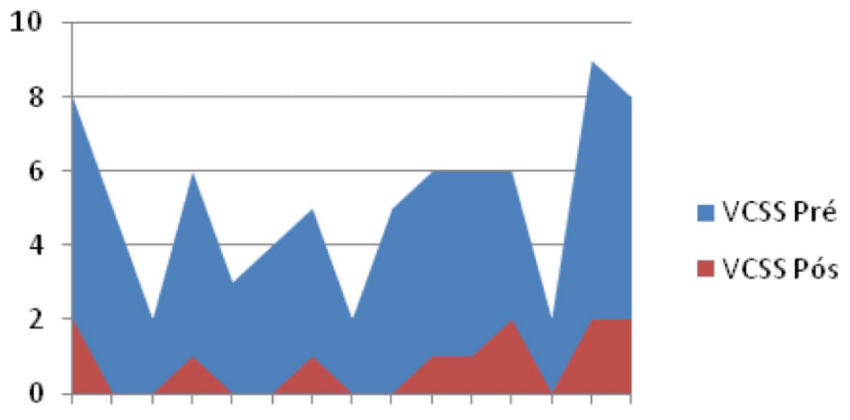

$\begin{array}{lllllllllll}1 & 2 & 3 & 4 & 5 & 6 & 7 & 8 & 9 & 1011 & 12131415\end{array}$

Figure 1 - Pre- and postoperative VCCS (Venous Clinic Severety Score) values.

Proximal Saphenous Vein

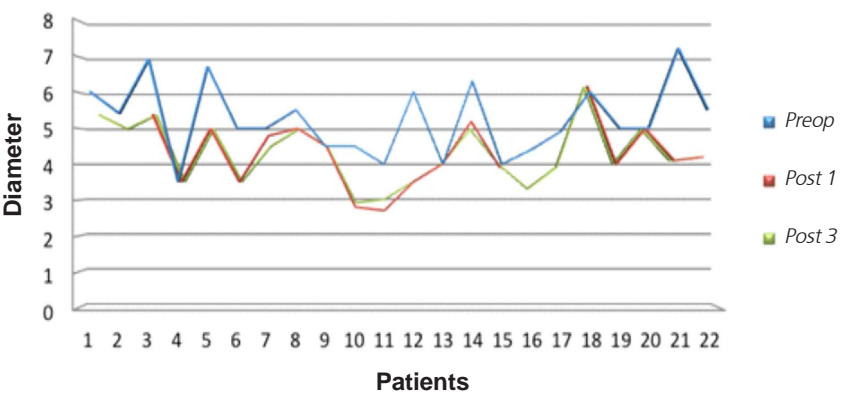

Figure 2 - Diameter of the great saphenous vein. 
Table 1 - Classification according to CEAP and VCSS criteria.

\begin{tabular}{|c|c|c|c|c|c|c|c|c|}
\hline Patients & $\begin{array}{l}\text { Limb } \\
\text { studied }\end{array}$ & Age & $\begin{array}{c}\text { Pre RLL } \\
\text { CEAP }\end{array}$ & $\begin{array}{c}\text { Post RLL } \\
\text { CEAP }\end{array}$ & $\begin{array}{c}\text { Pre LLL } \\
\text { CEAP }\end{array}$ & $\begin{array}{c}\text { Post LLL } \\
\text { CEAP }\end{array}$ & $\begin{array}{c}\text { Pre } \\
\text { VCSS }\end{array}$ & $\begin{array}{l}\text { Post } \\
\text { VCSS }\end{array}$ \\
\hline TMLT & RLL/LLL & 51 & 3 & 2 & 3 & 1 & 8 & 2 \\
\hline TLS & RLL & 47 & 3 & 2 & - & - & 5 & 0 \\
\hline TPA & RLL & 35 & 2 & 1 & - & - & 2 & 0 \\
\hline MS & RLL / LLL & 48 & 3 & 2 & 3 & 2 & 6 & 1 \\
\hline MJNS & LLL & 55 & - & - & 2 & 2 & 3 & 0 \\
\hline MCAN & RLL / LLL & 53 & 2 & 2 & 2 & 2 & 4 & 0 \\
\hline LSS & LLL & 28 & - & - & 2 & 1 & 5 & 1 \\
\hline LN & RLL & 29 & 2 & 1 & - & - & 2 & 0 \\
\hline DFFP & RLL / LLL & 50 & 3 & 2 & 3 & 2 & 5 & 0 \\
\hline ASI & RLL / LLL & 40 & 3 & 2 & 2 & 2 & 6 & 1 \\
\hline RML & RLL / LLL & 48 & 2 & 1 & 3 & 2 & 6 & 1 \\
\hline MCA & RLL / LLL & 49 & 3 & 2 & 4 & 2 & 6 & 2 \\
\hline MAG & MIE & 34 & - & - & 1 & 1 & 2 & 0 \\
\hline EPM & MIE & 34 & - & - & 2 & 1 & 9 & 2 \\
\hline $\mathrm{COC}$ & MIE & 47 & - & - & 4 & 4 & 8 & 2 \\
\hline
\end{tabular}

CEAP - clinical, etiologic, anatomic and pathophysiologic; RLL - right lower limb; LLL - left lower limb; VCSS - Venous Clinic Severety Score.

\section{DISCUSSION}

Radical saphenectomy plays a role in the treatment of chronic venous disease, but with increasingly limited indication, given its importance as a vascular substitute for various beds of the circulatory system. Associated with this, Pittaluga et al. ${ }^{17}$ showed that the great saphenous vein, when presenting with a diameter of approximately $7.5 \mathrm{~mm}$, shall, after the withdrawal of collaterals and the ligation of the perforating, decrease in diameter, with improvement or complete abolition of reflux, associated with improvement of clinical parameters, confirming the effectiveness of the proposed method. Nonetheless, it might be questioned that the diameter of the saphenous vein may have no direct correlation or be the only significant predictor ${ }^{18}$ associated with the symptoms.

Resection of varicose veins with preservation of the saphenous vein and venous reservoir resection ${ }^{17}$ restores venous flow, resulting in the beneficial effects to the saphenous vein, reducing signs and symptoms, and therefore the degree of venous disease of the patients thus operated.

Table 2 - Restoration of flow in the greater saphenous vein (GSV).

\begin{tabular}{lcccc}
\hline Patients & $\begin{array}{c}\text { RLL Preoperative } \\
\text { reflux }\end{array}$ & $\begin{array}{c}\text { RLL } \begin{array}{c}\text { Postoperative } \\
\text { reflux }\end{array} \\
\begin{array}{c}\text { LLLPreoperative } \\
\text { reflux }\end{array}\end{array}$ & $\begin{array}{c}\text { LLLostoperative } \\
\text { reflux }\end{array}$ \\
\hline TMLT & $\mathrm{P}$ & $\mathrm{P}$ & $\mathrm{P}$ & $\mathrm{A}$ \\
TLS & $\mathrm{P}$ & $\mathrm{P}$ & $\mathrm{P}$ & $\mathrm{A}$ \\
TPA & $\mathrm{P}$ & $\mathrm{P}$ & & $\mathrm{P}$ \\
MS & $\mathrm{P}$ & $\mathrm{P}$ & $\mathrm{P}$ & $\mathrm{A}$ \\
MJNS & $\mathrm{P}$ & $\mathrm{P}$ & $\mathrm{P}$ & $\mathrm{A}$ \\
MCAN & $\mathrm{P}$ & $\mathrm{P}$ & $\mathrm{A}$ \\
LSS & & $\mathrm{A}$ & $\mathrm{A}$ & $\mathrm{P}$ \\
LN & $\mathrm{P}$ & $\mathrm{P}$ & $\mathrm{A}$ & $\mathrm{P}$ \\
DFFP & $\mathrm{P}$ & $\mathrm{A}$ & $\mathrm{P}$ & \\
ASI & $\mathrm{P}$ & $\mathrm{P}$ & $\mathrm{P}$ & $\mathrm{P}$ \\
RML & $\mathrm{A}$ & $\mathrm{P}$ & $\mathrm{P}$ & \\
MCA & $\mathrm{P}$ & $\mathrm{P}$ & $\mathrm{P}$ & \\
MAG & & $\mathrm{P}$ & $\mathrm{A}$ & \\
EPM & & $\mathrm{P}$ & & \\
COC & & &
\end{tabular}

Legends: RLL - right lower limb; LLL - left lower limb.

P-presenT; A- absent 
Table 3 - Preoperative CEAP, VCSS and saphenous vein diameter.

\begin{tabular}{lccccccccc}
\hline $\begin{array}{l}\text { Patients / } \\
\text { Parameter }\end{array}$ & $\begin{array}{c}\text { Pre RRL } \\
\text { CEAP }\end{array}$ & $\begin{array}{c}\text { Pre LLL } \\
\text { CEAP }\end{array}$ & $\begin{array}{c}\text { Pre } \\
\text { VCSS }\end{array}$ & $\begin{array}{c}\text { SVD } \\
\text { right }\end{array}$ arch right thigh & $\begin{array}{c}\text { SVD } \\
\text { right leg }\end{array}$ & $\begin{array}{c}\text { SVD } \\
\text { left arch }\end{array}$ & $\begin{array}{c}\text { SVD } \\
\text { left thigh }\end{array}$ & $\begin{array}{c}\text { SVD } \\
\text { left leg }\end{array}$ \\
\hline TMLT & 3 & 3 & 8 & 6 & & 4.2 & 5.4 & & 3 \\
TLS & 3 & 2 & 5 & 6.9 & 4.7 & 3.5 & & & \\
TPA & 2 & 2 & 2 & 3.5 & 3.2 & 3.7 & & & \\
MS & 3 & 3 & 6 & 6.7 & 5 & 4 & 5 & 3.5 & 3.5 \\
MJNS & 2 & 2 & 3 & & & & 5 & 4.5 & 2.5 \\
MCAN & 2 & 2 & 4 & 5.5 & 3.7 & 3 & 4.5 & 2.5 & 2.5 \\
LSS & 2 & 2 & 5 & & & & 4.5 & 2.5 & 2 \\
LN & 2 & 2 & 2 & 4 & 3.5 & 2.5 & & & 2.2 \\
DFFP & 3 & 3 & 5 & 6 & 4.5 & 4.5 & 4 & 2 & 2.3 \\
ASI & 3 & 2 & 6 & 6.3 & & 4.7 & 4 & & 2.3 \\
RML & 2 & 3 & 6 & 4.4 & & 3 & 4.9 & & 3.1 \\
MCA & 3 & 4 & 6 & 6 & 5.5 & 5 & 5 & 5 & 4 \\
MAG & 2 & 1 & 2 & 6 & & & 5 & 3 & 3 \\
EPM & 4 & 2 & 9 & & & & 7.2 & & 3.6 \\
COC & 4 & 4 & 8 & & & & 5.5 & 4.5 & 4 \\
\hline
\end{tabular}

CEAP: clinical, etiologic, anatomic and pathophysiologic; RLL: right lower limb; LLL: left lower limb; VCSS: Venous Clinic Severety Score; SVD: saphenous vein diameter.

The decrease in diameter of the great saphenous vein without completely abolishing reflux can lead to clinical improvement by decreasing the volume of reflux ${ }^{18-20}$, since this is in direct proportion to its diameter.

Recently, less invasive methods with laser and radio frequency and even dense foam opened new horizons in the treatment of chronic venous disease with less invasive techniques, an outpatient basis and results comparable to conventional surgery ${ }^{21}$.

Prospective studies with longer follow-up are needed to define the method to be used in cases of dilation and greater saphenous vein insufficiency and in cases of venous symptoms recurrence in patients with chronic venous insufficiency.
The long-term follow-up of these patients may help elucidate the most effective method in the treatment of lower limb varicose veins, its success and recurrence rates, bringing a new, less invasive proposal, with fewer comorbidities, to the therapeutic arsenal of lower limbs varicose disease.

In the authors' view, the preservation of the great saphenous vein, even if dilated and insufficient, is possible. It provides improvement of symptoms and also preserves the best autologous vascular conduit replacement. The aging population and the emergence of new instruments may influence the choice of radical treatment of the great saphenous vein, but not modify the surgical outcome in the short term.

\title{
R E S U M O
}

\begin{abstract}
Objetivo: avaliar a eficácia do tratamento cirúrgico das varizes de membros inferiores com preservação da veia safena magna. Métodos: estudo prospectivo realizado em 15 pacientes do sexo feminino entre 25 e 55 anos com a classificação clínica, etiológica, anatômica e patofisiológica (CEAP) 2, 3 e 4. Os pacientes foram submetidos ao tratamento cirúrgico das varizes primárias dos membros inferiores com preservação da veia safena magna (VSM). Foram realizados exames com eco-Doppler no primeiro e terceiro meses de pós-operatório. O formulário da gravidade clinica da doença venosa, Venous Clinical Severity Score (VCSS) foi preenchido no pré e pós-operatório para graduá-la. Foram excluídos pacientes com historia de trombose venosa profunda, tabagismo, uso de meia elástica ou flebotômicos no pós-operatório. Resultados: todos os pacientes obtiveram melhora do VCSS $(P<0,001)$ e redução do calibre da veia safena magna $(P<0,001)$. Houve relação do VCSS com o calibre da VSM, assim como, com o CEAP no pré-operatório. Houve melhora da classe CEAP em nove pacientes comparado com o pré-operatório $(P<0,001)$. Conclusão: a operação de varizes com preservação da veia safena magna teve efeito benéfico à própria VSM, com a diminuição de calibre, e à sintomatologia quando a veia apresentava calibre máximo de 7,5mm, correlacionando-se diretamente com a CEAP. A diminuição do calibre da VSM mesmo sem abolição total do refluxo leva a melhora clinica por diminuição do volume de refluxo.
\end{abstract}

Descritores: Insuficiência venosa. Varizes. Veia safena. Veia safena/ultrassografia. Veia safena/cirurgia. 


\section{REFERENCES}

1. Labropoulos N, Giannoukas AD, Delis K, Mansour MA, Kang SS, Nicolaides AN, et al. Where does venous reflux starts? J Vasc Surg. 1997;26(5):736-42.

2. Porter JM, Moneta LG. Reporting standards in venous disease: an update. International Consensus Committee on Chronic Venous Disease. J Vasc Surg. 1995;21(4):635-45.

3. Labropoulos N, Leon L, Kwon S, Tassiopoulos A, GonzalezFajardo JA, Kang SS, et al. Study of the venous reflux progression. J Vasc Surg. 2005;41(2):291-5

4. Fiebig A, Krusche P, Wolf A, Krawczak M, Timm B, Nikolaus S, et al. Heritability of chronic venous disease. Hum Genet. 2010;127(6):669-74.

5. Tran NT, Meissner MH. The epidemiology, pathophysiology, and natural history of chronic venous disease. Semin Vasc Surg. 2002;15(1):5-12

6. Raffetto JD, Khalil RA. Mechanisms of varicose vein formation: valve dysfunction and wall dilation. Phlebology. 2008;23(2):85-98.

7. Sansilvestri-Morel P, Fioretti F, Rupin A, Senni K, Fabiani JN, Godeau $G$, et al. Comparison of extracellular matrix in skin and saphenous veins from patients with varicose veins: does the skin reflect venous matrix changes? Clin Sci. 2007;112(4):229-39.

8. Brand FN, Dannenberg AL, Abbott RD, Kannel WB. The epidemiology of varicose veins: the Framingham Study. Am J Prev Med. 1988;4(2):96-101.

9. Heit JA, Rooke TW, Silverstein MD, Mohr DN, Lohse CM, Petterson TM, et al. Trends in the incidence of venous stasis syndrome and venous ulcer: a 25-year population-based study. J Vasc Surg. 2001;33(5):1022-7.

10. Caggiati A, Rosi C, Heyn R, Franceschini M, Acconcia MC. Agerelates variations of varicose veins anatomy. J Vasc Surg. 2006:44(6):1291-5.

11. Meissner MH, Gloviczki P, Bergan J, Kistner RL, Morrison N, Pannier F, et al. Primary chronic venous disorders. J Vasc Surg. 2007:46 Suppl S:54S-67S

12. Maffei FH, Magaldi C, Pinho SZ, Lastoria S, Pinho W, Yoshida WB, et al. Varicose veins and chronic venous insufficiency in Brazil: prevalence among 1755 inhabitants of a country town. Int J Epidemiol. 1986;15(2):210-7.
13. Araújo AL, Ferreira RCA, Oliveira $C A B$. Semelhança morfológica entre lesões vasculares: varizes dos membros inferiores e aterosclerose. Rev Angiol Cir Vasc. 2007;6(1):29-33.

14. Engelhorn CA, Beffa CV, Bochi G Pullig RC, Cassou MF, Cunha SS A pletismografia a ar avalia a gravidade da insuficiência venosa crônica. J vasc bras. 2004;3(4):311-6

15. Nishibe T, Kudo F, Miyazaki K, Kondo $Y$, Nishibe M, Dardik A Relationship between air-pletismographic venous function and clinical severity in primary varicose veins. Int Angiol. 2006;25(4):352 -5 .

16. Pittaluga P, Chastanet S, Réa B, Barbe R, Guex JJ, Locret T Corrélation entre l'âge, les signes et symptômes de l'insuffisance veineuse superficielle et les résultats de l'exploration écho-Doppler Phlébologie. 2006;59(2):149-56.

17. Pittaluga P, Réa B, Barbe R. Méthode ASVAL (Ablation Sélective de Varices sous Anethésie Locale): principes et résultats préliminaires. Phlébologie. 2005;58(2):175-81.

18. Gibson K, Meissner M, Wright D. Great saphenous vein diameter does not correlate with worsening quality of life scores in patients with great saphenous vein incompetence. J Vasc Surg. 2012;56(6):1634-41.

19. Christopoulos D, Nicolaides AN, Szendro G. Venous reflux: quantification and correlation with the clinical severity of chronic venous disease. Br J Surg. 1988;75(4):352-6.

20. Joh JH, Park HC. The cutoff value of saphenous vein diameter to predict reflux. J Korean Surg Soc. 2013;85(4):169-74.

21. Nesbitt C, Eifell RK, Coyne P, Badri H, Bhattacharya V, Stansby G. Endovenous ablation (radiofrequency and laser) and foam sclerotherapy versus conventional surgery for great saphenous vein varices. Cochrane Database Syst Rev. 2011;5(10)CD005624.

Received on 15/03/2014

Accepted for publication 25/05/2014

Conflict of interest: none.

Source of funding: none.

Address for correspondence:

Bernardo Cunha Senra Barros

E-mail: dots.br@gmail.com 